\title{
STRIKES IN CHINA'S EXPORT INDUSTRIES IN COMPARATIVE PERSPECTIVE
}

\begin{abstract}
Anita Chan*
China's export industries witness outbreaks of spontaneous work stoppages and strikes that are often suppressed by the local authorities, sometimes with violence. To gain a perspective on these disturbances, and on what they reveal about China's industrial relations system, it is instructive to compare China with Vietnam. Even though the two countries have emerged from similar histories of Communist Party rule, their regulation of strikes is a study in contrasts. Chinese law does not mention strike actions, and as a result they are neither legal nor illegal. Vietnam, in contrast, has legislated complex provisions detailing when and how strikes can occur legally, and specifying the negotiations that must precede a strike. The intent is to regulate labor discontent by providing workers with a collective bargaining platform and with strike procedures when bargaining breaks down, so as to reduce the occurrence of wildcat strikes. We might therefore expect fewer strikes in Vietnam, where legal sanctions exist to regulate them, but the reverse is the case: China experiences less frequent strikes than Vietnam, which has had waves of wildcat strikes during the past five years. Also unexpected is that, even though the strikes in Vietnam are illegal, they are unimpeded by the authorities, who often in fact act in the interests of the strikers. In China, strikes which cannot be categorized as illegal are nonetheless usually suppressed vigorously by the authorities.

To understand this contrast in labor laws and their implementation, this article will compare the course of strikes in China and Vietnam and will then examine the underlying factors: the relationship between the government and the official trade union, the labor laws, the tripartite dispute-resolution institutions, and the minimum legal labor standards set by the government.

China and Vietnam both had a planned command socialist economy in the past, and within the past several decades both countries have gone a long way toward dismantling that system, turning to the market and integrating with global capitalism. Unlike most other former socialist states, which have become

I am indebted to Professor Wang Hongzen of Zhongshan University, Taiwan, who collaborated with me in a research project on Taiwanese businesses in Vietnam and China, funded by the Chiang Ching-Kuo Foundation. Thanks are also due to Thuy Thu Pham for collecting Vietnamese documentary materials, to Jonathan Unger for his comments and editing, and to two anonymous referees for The China Journal for their detailed comments.
\end{abstract}


multiparty political systems, the two Asian neighbors remain one-party regimes under their respective Communist Parties. As Leninist states, both countries prohibit autonomous trade unions and instead grant a monopoly to official trade unions that are under Party-state control, the All-China Federation of Trade Unions (ACFTU) and the Vietnam General Confederation of Labor (VGCL). Why, then, despite these similarities, are the two industrial relations systems diverging?

To increase comparability, my field research has focused largely on factories owned and managed by Taiwanese companies, which share a similar style of management. More specifically, the research has focused on footwear factories. Different industries are apt to possess somewhat dissimilar work conditions, hire somewhat different types of workers, and give rise to somewhat different worker grievances which result in different courses of industrial action. Focusing largely on one industry in both countries avoids the pitfalls of studying dissimilar work situations. In each country, I focused my research on a region where Taiwanesemanaged factories are heavily concentrated.

\section{Comparing Strikes in China's Pearl River Delta and Vietnam's Ho Chi Minh City ${ }^{1}$}

In China, the cities of Dongguan and Shenzhen in the delta region of southern Guangdong Province are crowded with large numbers of Taiwanese factories. Starting in the late 1980s, labor-intensive industries relocated from Taiwan to Dongguan in abundance, and as of 2008-09 Dongguan contained some 6,000 Taiwanese factories. The number of strikes there has been increasing and, according to a 2008 report, sometimes reaches three or four in the same weeks, but this figure includes factories owned by other nationals, not just Taiwanese. ${ }^{2}$ Despite this rise in strikes, Taiwanese investors who were interviewed who own factories in both Vietnam and China do not see strikes in China as a problem.

In contrast, these same Taiwanese businesspeople are concerned about strikes in Vietnam. Strike waves began to erupt in Vietnam in 2006 (350 officially recorded strikes) and reached a peak in 2008 (762 strikes). ${ }^{3}$ There was a drop to 215 in 2009, the year of global economic recession, ${ }^{4}$ but once the economy picked up in 2010

1 For further reasons that these two regions and Vietnam and China as a whole are worth comparing, see William S. Turley and Brantley Womack, “Asian Socialism's Open Doors: Guangzhou and Ho Chi Minh City", in Transforming Asian Socialism: China and Vietnam Compared, edited by Anita Chan, Benedict J. Tria Kerkvliet and Jonathan Unger (Boulder: Rowman \& Littlefield, 1999, and St. Leonards: Allen \& Unwin, 1999), pp. 44-73.

2 Liu Jianqiang, "Gongren bagong buduan, yuanzi dui xin laogongfa wujie jiashen" (Workers' Strikes Non-stop Due to Misinterpretation of the New Contract Law), Zhongguo Qiyejia (China Entrepreneur), 14 February 2008.

3 See Benedict J. Kerkvliet, "Workers' Protests in Contemporary Vietnam", in Anita Chan (ed.), Labour in Vietnam (Singapore: Institute of Southeast Asian Studies Press, forthcoming 2011), Chapter 6, Table 6.1.

4 "So vu dinh cong nam 2009 chi bang 30\% nam 2008" (Number of Strikes in 2009 Are Just $30 \%$ of 2008), Laodong, 5 January 2010. 
the strikes resumed, hitting the 200 mark in the first six months. ${ }^{5}$ They are most frequent in the export sector in Ho Chi Minh City (HCMC) and the surrounding provinces, where Taiwanese-invested firms are concentrated: firms from Taiwan, the third largest investor nation in Vietnam, operate some 2000 to 3000 factories there. According to the Taiwanese newspaper Zhongguo shibao (China Times Daily 中国时 报), Taiwanese firms have been particularly targeted, accounting for a disproportionate number of strikes, which has caused alarm among the Taiwanese business community. In Binh Doung Province, home to more than 500 Taiwanese factories in 2006, a strike wave swept more than 50 Taiwanese factories at the same time, and all of them had to stop production. ${ }^{6}$ In the years since, strikes have remained a regular phenomenon. Taiwanese factory owners reportedly greet each other nowadays with the anxious query, "Has your factory been affected by a strike yet?" In 2010 a Taiwanese blogger wrote that only when one has not been targeted by strikers is it newsworthy.

This difference in the incidence of labor stoppages goes against the findings of a previous study in which I participated, which compared Taiwanese labor practices in Vietnam and China. ${ }^{8}$ That study discovered that Taiwanese bosses treated Vietnamese workers better than they treated Chinese workers. Our article concluded that the attitude of the Vietnamese government and the official trade union toward labor violations by foreign investors has been the most salient factor in influencing how Taiwanese management treated workers. When newly collected data show that Vietnamese workers are actually more prone to strike than their Chinese counterparts, a reinvestigation of materials is warranted.

The new information comes from diverse sources. In particular, a number of research visits were made to each of these two regions, and factory managers were interviewed in both. ${ }^{9}$ There was no attempt to conduct interviews with workers while inside factories, but we interviewed them outside factory premises as workers left work. In both countries, extensive interview sessions were held with locally based staff members of a well-known Western-owned footwear company that sources from supplier factories in both Vietnam and China. In addition, interviews were held with government and trade union officials and, in China, with the staff of labor NGOs stationed in Shenzhen.

5 "Vietnam Records 200 Strikes in January-June: Ministry", Investment in Vietnam, www.investinvietnam.vn/Default.aspx?ctl=Article\&tID=0\&pID=120\&aID=1931 (accessed 24 July 2010).

6 Jiang Huizhen, "Strike Waves in Vietnam: Some Taiwanese Businesses Consider Divesting”, Zhongguo shibao (China Times Daily), 1 August 2006.

7 Lianhe zaobao wangxun (United Daily News Net), 29 October 2007.

8 Anita Chan and Wang Hongzen, "The Impact of the State on Workers' Conditions: Comparing Taiwanese Factories in China and Vietnam", Pacific Affairs, Vol. 77, No. 4 (Winter 2004), pp. 629-46.

9 Most of these interviews with management were arranged by Wang Hongzen, and the two of us carried out the interviews together in both countries. 
These field visits were complemented by extensive documentary research. These include Chinese-language materials from Taiwan and China, some very detailed reports on Chinese strikes posted on the Internet by international and Hong Kong-based NGOs, and media reports regarding labor disturbances in Vietnam written in Vietnamese and English.

Coverage of strikes in the Vietnamese press is plentiful, in particular in Laodong (Labor) and Nguoi Laodong (Laborer), sometimes followed up by investigative reports complete with strike photos and statistical data. The Chinese press had refrained from reporting on strikes in Guangdong's Pearl River Delta in the 1990s but, with Chinese Internet bloggers multiplying at a rapid rate, news about strikes can no longer be swept under the carpet. Since the mid-2000s, press reports on strikes have also begun surfacing in the Chinese news media, although seldom illustrated by photos of mass protests, protest banners or police vansimages of street actions remain off limits. The Internet and Hong Kong press photographers sometimes make up for this blackout inside China.

The Vietnamese government keeps a record of the number of strikes, which is regularly reported in the press. For China, I have yet to come across similar official statistics, possibly because strikes are not officially recognized as legitimate collective actions. China only releases figures on "labor disputes" (laodong zhengyi 劳动争议) or "mass incidents" (qunzhong shijian 群众事件). The statistics for "labor disputes" involve cases of individual or collective disputes formally accepted by the authorities for processing but which may or may not reach the stage of arbitration and litigation. ${ }^{10}$ The term "mass incidents" refers to collective protests with the implication that violence has occurred; some of them could be strikes and some not.

In order to analyze the nature of strikes and industrial relations in the two countries, it is best first to describe one representative example of a strike in Vietnam and in China to give readers a sense what these typically are like-what instigates workers to take up collective protest action, what the workers' grievances are, what their demands are, how they behave during the strike, what the level of worker solidarity is, what actions management engages in, how the trade union, local government and police handle the incidents, and finally, how the strikes end, what the terms of settlement are and what roles are played by stakeholders, including labor advocates and the major corporations that purchase from the factory.

\section{China: Confrontation at a Footwear Factory}

This strike was widely reported inside and outside China on the Internet, including web blogs. Several such reports tracked the development of the dispute over a period of several months. ${ }^{11}$

10 Shenzhen laodong zhengyi zhongcai wang (Shenzhen Industrial Dispute Arbitration Network), www.szlaodong.com/laodongzhengyidiaojiezhongcaifajieshi/, accessed 15 April 2010.

11 See, for example, Zhongguo xinwen zhoukan (China News Weekly), 26 November 2004; Baoxun (Comprehensive News), 2 November 2004; CSDN net, 18 January 2006; China Labor Watch, 28 August 2004, 1 January 2005. 
Stella Footwear Company (real name) is Taiwanese-owned. In 1991, like many Taiwanese factories, it relocated from Taiwan to Dongguan City. A decade later it had expanded into five facilities in different parts of Guangdong Province, two of which were in Dongguan. It employed about 60,000 workers and supplied shoes to some ten brand-name companies, including Nike, Reebok, Timberland and Clark. None of the five Stella factories contained trade union branches.

The work hours were long at these factories: up to 11 hours a day, 6 days a week. Workers were paid a so-called monthly basic wage for the first 40 hours of the workweek. Like all factories in Dongguan, this basic monthly wage as of 2004 was 450 yuan (US\$54.50), set exactly at the official minimum wage (similarly in Vietnam, factories pay a basic wage that is exactly the official legal minimum wage). With overtime, that year workers made on average 700 yuan a month at Stella. Eighty per cent of the workers lived in cramped company dormitories. After deducting money for rent and food, workers were left with only some 200 yuan (US\$24.20) per month in take-home pay. Without the overtime work of some 20 to 26 hours a week, the workers would have had no take-home pay.

In March 2004, Stella management suddenly reduced the amount of overtime work by giving workers two more days off a month, causing a drop in income of about 100 yuan for each worker. The problem was that, although working hours were reduced, the work quota remained unchanged - meaning that workers still needed to produce as many shoes as before-which effectively meant an increase in labor intensity alongside a decrease in their monthly income. On pay day, when workers saw the pay cut in their wage package, they became angry. Some workers began calling in unison, "Higher wages! Better food!", and soon afterwards a crowd of more than a thousand workers started smashing machinery, rushed into staff offices, breaking windows, looting the factory grocery store and overturning vehicles. A corps of thirty security guards could not control the crowd. Police were called. "In the chaos the workers had no leaders, no representatives, no organization and no concrete demands. They dispersed as quickly as they rose up." ${ }^{\prime 2}$ The news of the conflagration spread, and four out of five Stella factories were engulfed by violence. This on-site violence is not commonplace in Chinese industrial actions; a more normal situation is for workers to take to the streets, marching to the local authorities to seek redress. The police then arrive in large numbers to try to stop the march, which in turn can result in violence and arrests.

In the end, more than 1,000 Stella workers were fired, 70 were arrested and 10 were charged by the local government with destroying property and quickly sentenced to between three and three-and-a-half years in prison. The youngest was only 16 years old. Immediately, international and Hong Kong NGOs launched a protest campaign for the release of the 10 convicted workers. Six Chinese lawyers, including a well-known human rights lawyer, were hired and traveled to Dongguan to

12 Zhongguo xinwen zhoukan, 26 November 2004. 
represent the workers. ${ }^{13}$ Campaign organizers urged the footwear brand-name companies to use their leverage to ask the Dongguan government for the workers' release. On 1 January 2005 all ten were released with suspended sentences. According to follow-up reports, work conditions reverted to what they had been in earlier months - the two days of monthly weekend overtime were restored and monthly wages remained at previous levels. The brand-name companies organized management-worker training sessions at the factories in the hope of establishing more stable labor relations.

I was able to talk to several Stella workers outside the factory in September 2007. Their accounts suggested that there was still a lot of overtime work and the pay was average for the district. They also said that they were trying to organize other workers to set up a democratically elected union, which they hoped to register with the higher-level local union. None of their hopes became reality.

\section{Vietnam: A Spontaneous Strike's Negotiated Conclusion}

As a typical example, I have chosen a strike that broke out in one of the several factory sites of ABC Footwear Company (a pseudonym) in March 2006. This is one of the earliest Taiwanese footwear factories established in Vietnam and it produces exclusively for one Western brand-name company. ABC employed 50,000 workers at this one site. As required by Vietnamese law, it allowed a trade union branch to be set up in 1996, but the trade union has not been proactive in representing workers' interests. For example, during an interview the union chairperson described the relationship between the union, workers and the company as one of "partnership". His attitude was that "the trade union will stand up for workers' interests if the company infringes the law. We will propose suggestions to the company, but if it does not accept them it is the company's responsibility, not the union's." (Thus, implicitly, if the workers stage a strike it is the management's fault rather than the union's.) From his vantage point, the trade union has to work in cooperation with various departments in the company and it is not his job to struggle for workers' interests.

In the months leading up to the ABC strike, the trade union had notified management that workers had some serious grievances. They were unhappy that every time a new shoe model came on line, productivity initially dropped, causing a reduction in their monthly "production quantity bonus". Management's attitude was that this was not a problem, as long as the factory did not breach the law and the client's corporate code of conduct. It did not heed the trade union's advice. In a round-table discussion that we held with trade-union committee members inside the factory in 2006, they expressed their frustration but at the same time said that they would not push management to the point that their relationship with management became confrontational. The result: workers did not trust the trade union

13 One of the lawyers was Gao Zhicheng, a well-known human rights lawyer who, for his efforts in a different case, was sentenced in December 2006 to three years' imprisonment for incitement. After he was released, he disappeared into detention again in March 2010. 
and some of them even publicly challenged the trade union chairperson, calling upon him to step down.

In September 2005, at a time of high inflation, the Vietnamese government had announced an increase of some 40 per cent in the legal minimum wage for FDI enterprises (870,000 Dong [about US\$55] per month for the HCMC region and Hanoi). ${ }^{14}$ Factory managements complained that the announcement gave them too little time to arrange for a wage increase. The government then delayed the increase, to come into effect as of 1 April 2006. The workers, impatient with the half-year delay, organized a wave of strikes after the announcement. To appease them, the government gave in and rescheduled the date to 1 February, causing great confusion.

Despite the minimum-wage rise, a wildcat strike broke out after workers returned to ABC Factory from the Tet holidays in early March 2006. On 10 March, a Friday, the company discovered call-for-strike leaflets posted on walls and placed at a number of production lines. Management had no idea who had organized this, nor did the workers whom we interviewed subsequently. Management immediately decided to give workers a day off on Monday in the hope of averting the strike, but not all workers were informed about the day off. On Monday, some turned up for work, but striking workers blocked them from entering the factory. A few angry workers started throwing stones at the office buildings. Some office staff managed to get to their offices, but anonymous phone calls using the internal phone line intimidated them into leaving. As each staff member emerged from the factory gate, crowds of strikers who were gathered outside the gate cheered and applauded.

That morning, local government officials, including officials from the labor bureau and the provincial trade union, arrived to mediate the dispute. They talked to the workers and noted down their complaints. The police also showed up, but according to management "the police did nothing". When management staff tried to take photos of the most active and vocal strikers, the police stopped them on the grounds that "it might irritate the crowd, leading to unexpected consequences". Management pointed out that the blockade was illegal, but the police did not take any action.

Management then asked the trade union to present a list of the workers' demands, but the trade union could not represent the workers, and no strike leaders would step forth from among the workers. Under such circumstances, government officials and provincial trade union officials sat at the negotiating table, presenting the workers' demands to management representatives. The demands included 1) raising wages for senior workers; 2) contributing to social security for workers; and 3) paying a seniority allowance. Senior workers demanded a wage increase because, when $\mathrm{ABC}$ increased the basic wage in accordance with the minimum wage rise as of 1 February, as required by the government, the junior workers' increase was higher

14 The minimum wage was different for other regions: 790,000 Dong (\$50) for Hai Phong, Ha Long, Da Nang, Nha Trang, Vung Tau and Can Tho, and 710,000 (\$45) for other areas. 
in proportion to their wage than that of senior workers. The latter thought this unfair and agitated for a bigger increase. The company already had an annual incremental wage system policy based on seniority, but it was not formalized. Thus, during the negotiations the workers demanded that this seniority system be included in the collective agreement - though this amounted to an annual increment of merely VND 25,000 (about US\$1.80). Management accepted the three demands.

The negotiations lasted for three days, during which the workers did not return to work, but they still received their salaries. When the negotiations were wrapped up, management warned that strikers who did not turn up for work on Thursday would get a demerit and no pay. However, the company could not legally fire those who did not turn up for work on Thursday.

An interviewee who was representing management at the negotiating table was convinced that "the Vietnamese government is behind the scenes. On the surface it appears to be taking a laissez-faire attitude, but whenever there's a strike, it becomes a mediator and presses businesses to accept workers' demands."

\section{Comparing the Two Cases}

I have chosen these two strikes in large part because they are representative of strikes in each of the two countries. One typical aspect is that in neither factory was an official workplace union involved. At ABC there was a union, but it played no role in the entire process. Despite its legal status, it was not even present at the negotiating table. At Stella, as noted, there were no unions at the five production sites. This reflects a typical phenomenon in both regions-workplace unions often do not exist in the foreign-run export factories in China or exist only in name, while in Vietnam, where they do exist, they are extremely weak and distrusted by workers. ${ }^{15}$ However, Vietnamese workplace unions, as exemplified in ABC, may sometimes serve as a channel of communication between management and labor to defuse extreme tensions. When a union cannot quietly convince management to resolve grievances, though, bottled-up frustration can turn into collective protest actions. In both countries, these strikes are "spontaneous", and in both cases viewed there had been no orderly representation made to management on behalf of the workers before strike actions began, though some worker activists inside ABC were organizing covertly. The Stella strike, in contrast, exploded into mass action without any covert planning. Herein lies one of the differences between strikes in the two countries. As strike waves spread across the HCMC region month after month and year upon year, Vietnamese workers learned from each other about how to start a wildcat strike, and have become emboldened by the experience. In China, contrary to Vietnam, there has often been no orderly way to resolve the strike through a negotiated compromise. From newspaper and Internet reports, I have been able to collect a sample of 105 Vietnamese strikes that were reported during 2007:

15 Wang Hongzen, "Asian Transnational Corporations and Labor Rights: Vietnamese Trade Unions in Taiwan-invested Companies", Journal of Business Ethics, Vol. 56, No. 1 (2005), pp. 43-53. 
most of them lasted only one day, and rarely did they last more than five, indicating that issues were resolved quite quickly.

Workers' demands in the two countries are not the same, also illustrated in the two case studies. At ABC in Vietnam, workers were asking for higher pay, better food, coverage for social security, a stepped wage structure, a seniority system and dignified treatment. These demands are representative of those made by most Vietnamese workers. ${ }^{16}$ Based on a breakdown of 70 strike cases that took place in 2007 and were reported in the Vietnamese press or on the Internet, the most recurrent cause was low pay, followed by insufficient wage increases to offset galloping inflation. The next most numerous complaints were related to the Tet bonus. Workers claimed that the bonus was not commensurate with their work contribution. Some complaints had to do with employers withholding the Tet bonus until after the workers returned from the holiday. Too much overtime was also often an issue. Workers complained about being forced to work extra hours or shifts and not being awarded the legal overtime premium. Similarly, failure to pay health and social insurance regularly surfaced as a grievance, but generally was not the catalyst that sparked collective protests. Finally, some workers also demanded a decrease in work quotas and an increase in piece rates. Unpaid wages or complaints over management breaching the law were seldom cited as causes.

In contrast, Chinese workers most often strike for different reasons and their demands are different. The Stella case provides a good example. Wages here were a major issue, but the strike was not over an insufficient wage increase; on the contrary, it was over an income reduction through less overtime work, which management accomplished by speeding up production during regular work hours. The dispute involved workers trying to protect what they had, rather than asking for more.

According to one study of strikes in Western countries, a sudden relative decline in wages or work conditions is more likely to trigger wildcat strikes than ongoing poor work conditions or low wages. ${ }^{17}$ Workers get incensed and react swiftly and spontaneously. The most detailed study available of a strike in China has been undertaken by Chris Chan at a Taiwanese-owned factory, and it is of this type. The strike was sparked off by a management "rationalization" policy that left workers with less time to eat lunch. ${ }^{18}$ At another factory in 2008, workers suddenly saw their wages cut by up to several hundred yuan, and outraged workers immediately quit work, blocked the factory gate and then rushed out to block traffic. ${ }^{19}$

16 For a comprehensive discussion of the causes leading to strikes in Vietnam, see Benedict J. Kerkvliet, "Workers' Protests in Contemporary Vietnam".

17 Martin J. Mauro, "Strikes as a Result of Imperfect Information", Industrial and Labor Relations Review, Vol. 35, No. 4 (1982), pp. 522-38.

18 Chris King-Chi Chan, The Challenge of Labour in China: Strikes and the Changing Labour Regime in Global Factories (Abingdon: Routledge, 2010), pp. 82-121.

19 For example, "Guangdong Foshan subai yuangong bumang Jiangxin dulu wu xiaoshi" (Several Hundred Workers in Guangdong Foshan Dissatisfied with A Drop in Wage Went to Block Roads), Yangcheng Evening News, 27 December 2008. 
What would have surprised Vietnamese workers was that Stella workers fought only to maintain their previous wage level, not for a wage rise. While Vietnamese workers fight for reduced work hours, Stella workers fought to have their reduced overtime restored! By law they are entitled to 4 days of rest a month, but they fought to go to work for 2 of those 4 days. Because they had not fought for higher pay rates, they could not afford to lose two days of overtimean amount, notably, that exceeded the legal maximum number of hours of work. Also, instead of fighting for a reduction in their work quota, they were willing to maintain the previous quota: they did not take advantage of the strike to ask for shorter work hours and better pay. They have a confused understanding of the integral relationship between wages, work hours and work intensity. ${ }^{20}$

The Stella workers' lack of understanding of the kind of demands that could improve their wage and work conditions was not unusual. In China's Pearl River Delta, workers' expectations generally are low. The majority of labor disputes are over seriously delayed payments of wages. ${ }^{21}$ When the delay drags on for too long, in reality it becomes unpaid wages. Workers' claims of unpaid wages almost always spike just before Chinese New Year (the same holiday as Tet), leading to much uncoordinated labor unrest. The situation had become extremely serious in the 1990s in Guangdong Province, reaching 5.6 billion yuan (about US\$190 million) of unpaid wages in 1998. To appease angry workers, local governments in places like Dongguan launched "chase back-wage campaigns". ${ }^{22}$ According to one survey, 73 per cent of Chinese migrant workers in the early 2000 s suffered varying degrees of wage defaults. ${ }^{23}$ In an effort to restore "social harmony", local governments have tried to use administrative methods to reduce the problem, but even then, in 2005 owed-wage cases still made up 41 per cent of labor dispute cases in the province. ${ }^{24}$ In Vietnam, delayed wage payments also exist, but these pale into insignificance in the accounts that I found of Vietnamese strikes. Simon Clark's findings concur: "Low wages, rather than unpaid wages, was an issue cited in one-third of reports on strikes in the period 2002-04". ${ }^{25}$

20 For a discussion on Chinese workers' lack of comprehension of the relationship between working hours and wages, see Anita Chan and Kaxton Siu, "Analyzing Exploitation: The Mechanisms Underpinning Low Wages and Excessive Overtime in Chinese Export Factories", Critical Asian Studies, Vol. 42, No. 3 (June 2010), pp. 167-90.

21 See also Pun Ngai and Lu Huilin, "A Culture of Violence: The Labor Subcontracting System and Collective Action by Construction Workers in Post-Socialist China", The China Journal, No. 64 (July 2010), pp. 143-58.

22 For example, "Yuangong jiti shangfang tao gongzi, zhengfu juche gongdao ping minfen" (Employees Collectively Ask for Wages, The Government Adjudicates to Quell People's Wrath), Guangdong laodong bao (Guangdong Labor Newspaper), 1 March 1999.

23 “Laboring over Workers' Rights", Beijing Review, 25 December 2003, pp. 46-47.

24 Guangzhou Daily, 14 August 2007, p. 2.

25 Simon Clark, "The Changing Character of Strikes in Vietnam", Post-Communist Economics, Vol. 18, No. 3 (2006), pp. 351-52. 
There is no "chase back-wage campaign" in Vietnam. The irony of the protests before Tet and Chinese New Year is that, while Vietnamese workers were protesting against a delayed bonus payment or demanding a higher bonus, in China workers were trying to get paid, period.

There was one other type of serious workplace conflict in China that is often overlooked by observers - the issue of workers being refused permission to quit a job. It is a problem that does not seem to exist in Vietnamese Asian FDI factories. In China a widespread management practice has been to withhold a couple of months of workers' wages at the time of recruitment as a method of preventing workers from quitting when they want to. An inability to leave a factory with full pay and entitlements was a cause of great anxiety among Chinese migrant workers and was often a source of serious conflict on the shop floor, because supervisors have usually had the power to decide on whether to grant workers permission to resign. Workers desperate to leave without permission have had to forfeit the amount withheld when they started working.

The two cases also diverge with regard to how the two countries' local governments and trade unions handle strikes. Generally, strikes in the HCMC region can be characterized as peaceful, despite occasional skirmishes between a factory's private security guards and strikers. Vietnamese workers ordinarily display restraint and do not resort to violence. The local authorities, the district trade unions and the media quickly learn about an incident either from the workers or from management, and rush to the scene. When the authorities arrive, they try to calm the crowd, discuss the grievances, ask workers to choose representatives and then begin negotiating with management on behalf of the workers for better conditions and wages. The local authorities and the trade union quickly take on the role of the workers' representative in these negotiations. Often, according to Vietnamese newspaper reports, they lambaste the managers for mistreating workers. The length of the strike depends on the progress of the negotiations and on whether workers are willing to accept the terms that management offers. Since most strikes last only one or two days, this means that, in the face of pro-labor local authorities, management normally accedes quickly to workers' demands. In a minority of cases, when both workers and management are adamant, as in a strike at Hue Phong, the strike can last for a few weeks.

What distresses and frustrates Taiwanese investors is their conviction that the Vietnamese authorities side with the workers. "They are supposed to come to mediate, but basically they are here to fight for the workers. It's all one-sided", complained the Hue Phong director to me in 2007. "The workers here have better protection than workers in Taiwan!"

Taiwanese employers' treatment of workers and their attitudes towards strikes are very different in China. In this, the attitude of the host governments is critical. ${ }^{26}$ Thus a Taiwanese manager lamented, "We can't use in Vietnam the methods we use in China. Definitely a no-no." Why? "Because the mainland Chinese government

26 Anita Chan and Wang Hongzen, “The Impact of the State on Workers' Conditions”. 
supports us". While the Vietnam government does not let the police or factory managers suppress strikers, the Chinese local governments have no qualms about quelling strikes by sending in large numbers of riot police to intimidate workers. The Chinese and Hong Kong press repeatedly describe how workers move out onto the streets, the police arrive and the atmosphere grows more tense. Only occasionally does a strike end peacefully.

During 2008-09, in addition to unpaid wages and wage deductions for dormitory rents and food, workers' protests in Guangdong's Pearl River Delta have had to do with plant closures triggered by the rapid downturn of the global economy. When factory owners absconded, the workers had often not been paid for a few months, and they also lost entitlements. ${ }^{27}$ Ironically, some of these factories shut down in order to relocate to Vietnam to take advantage of the lower wages there. In most cases, factory management has been breaching the labor law and the workers feel that they have the right to take collective action when all other channels are blocked. Normally some of these workers would first have tried using legal means, through formal complaints to the local authorities and the district trade union. If the authorities were responsive and helped them get back their wages and severance pay, the dispute could be resolved without further incidents. As the economic downturn deepened in 2009 in the export sector, resulting in larger numbers of factory closures and labor disputes, local governments were sometimes more ready to accommodate workers' demands temporarily, to avoid aggravating tensions. ${ }^{28}$

Still, when they have been unable to get a sympathetic hearing from local authorities, workers have drawn public attention to their grievances by escalating collective protest actions. Many of these have taken the form of workers rushing out of the factory gate, marching in formation to the offices of the local authorities, blocking major roads or staging sit-ins inside or outside factory compounds. ${ }^{29} \mathrm{~A}$ large number of police appear on the scene to cordon off the strikers and prevent them from marching, driving them back into the factory compound or dispersing the crowds. In the process, violence breaks out and workers get arrested, thrown into police vans and charged with disturbing the peace. ${ }^{30}$ Because employers are

27 Agence France Presse, 18 October 2008; Beijing Times, 18 October 2008.

28 Information from a telephone conversation with a veteran staff member of a Shenzhen labor NGO, 3 November 2010. Despite the accommodations, official violence still sometimes flared up and ended with arrests. See, for example, Nanfang dushi bao (Southern City Daily), 26 November 2008.

29 This was exactly what happened in the two cases of strikes described in Chris King-Chi Chan and Pun Ngai, "The Making of a New Working Class? A Study of Collective Actions of Migrant Workers in South China", The China Quarterly, No. 198 (June 2009), pp. 287303. Workers knew that they would not get the support of the local government and had to take to the streets and blocking roads, triggering a large police presence that resulted in violence and arrests.

30 See, for instance, Ching Kwan Lee, Against the Law: Labor Protests in China's Rustbelt and Sunbelt (Berkeley: University of California Press, 2007), Chapter 5. 
often at fault, those arrested are often released on the same day or the next, after a beating. ${ }^{31}$

Therefore, unlike Vietnamese workers, Chinese workers who engage in protest actions do not expect the state to be on their side. It is desperate behavior carried out in full expectation of violent reaction. They calculate that, since the factories are legally in the wrong, when the upheaval is over local government officials will use their authority to demand that management abide by the lawsraising wages to the legal minimum required, or reducing excessive overtime, or paying severance compensation. The outcome is unpredictable, but they anticipate the likelihood of violence and suppression. Arrests (or driving strike leaders to flee to their hometowns), and allowing management to retaliate against workers after the dust settles through mass layoffs and blacklisting, make it difficult for activists to form organizing cells.

There have been some anomalies where Chinese labor protests resemble Vietnamese protests. The best-documented was a series of strikes in 2005 that spread across 18 factories (16 Japanese and 2 Korean) within a period of three months. ${ }^{32}$ There appears to have been some surreptitious organizing and coordination. As a result of these strikes, average wages increased by 100 yuan. At the end of August 2010, a much bigger wave of strikes hit 73 factories in the zone. Workers demanded a hefty rise of 800 yuan; in the end they settled for 300 yuan, a 34.5 per cent increase.$^{33}$ Like the Vietnamese workers, these strikers' demands were interest-based - asking for higher wages, better benefits and a higher overtime premium. The city authorities and the development zone trade union, on the other hand, were hostile towards the strikers. The trade union acted as a government representative. When the strikes spread, the development zone union became somewhat sympathetic to the workers' cause but, in the end, because the city government and Communist Party committee were worried that the strikes might deter investment, the union only played the role of mediator. Vietnamese authorities appear to be less worried that strikes might deter foreign investors, perhaps in the belief that Vietnam has other advantages to offer. ${ }^{34}$

\section{Underlying Factors}

How do we account for the differences in the two countries' strike patterns? Several factors can be identified - the relationship between the government and the official trade union, the labor laws and legal regulatory regime, the tripartite dispute-resolution institutions, and the minimum legal labor standards set by the government. Of these, the relationship between the government and trade union

31 My contacts at grass-roots Chinese labor NGOs observed that this is the general situation.

32 Feng Chen, "Trade Unions and the Quadripartite Interactions in Strike Settlement in China", The China Quarterly, No. 201 (March 2010), pp. 104-24.

33 Zhongguo jingying wang (Chinese Management Net), 20 September 2010.

34 Don Lee, "Multinationals Take a Longer View of Vietnam", Los Angeles Times, 11 April 2009. 
creates the macro political, institutional and legal parameters within which the other factors play out their differences.

\section{Government-Union Relations}

Both Vietnam and China are one-party states with corporatist structures. As described above, there are differences between the two in how the state handles strikes. This difference has historical roots. A vibrant trade union movement existed in South Vietnam in the 1960s and 1970s. ${ }^{35}$ In China, a genuine trade union had existed in a more distant past, before 1949, and the passage of time means that there are no personal memories of this. By 1980, when China began to allow the emergence of capitalist activity, the ACFTU contained only a few elderly officials who had experienced an independent trade union movement. ${ }^{36}$ In contrast, the legacy of a militant labor history in South Vietnam was of direct pertinence, especially in this region of Vietnam where a bureaucratic socialist system has never taken root. Some trade unionists' previous experiences probably had an influence on Vietnamese industrial-relations policy under doi moi (the reform period that started in 1986).

At the Sixth Vietnamese Trade Union Congress in 1988 the Party-state was willing to give space to the VGCL to operate under the slogan of "renewal, openness and democracy". ${ }^{37}$ The trade union structure was decentralized, and disagreements between the VGCL and the government over policy issues were allowed to be reported in the press. This has not been possible in China. The ACFTU has been striving for some independence from the Chinese Party-state, but any differences with the Party and other sectors of the government cannot be aired in public. The public can only construe that differences exist by reading between the lines in the media.

By the early 1990s, both countries had to enact a set of new labor laws to regulate a rapidly changing economic structure which was being challenged by expanding private and foreign-invested sectors. Strikes in the foreign-invested sector were of concern to the authorities in both countries, and like today the Chinese were apt to use force to suppress strikes. The Labor Law and the Trade Union Law that were passed in both countries at about the same time in the first half of the 1990s, after intense debates and several dozen drafts, laid the foundations of divergence. As a whole these bodies of laws guarantee more independence to the VGCL than to the ACFTU. The articles regulating collective bargaining in the Vietnam law are far more detailed. According to the Vietnamese Trade Union Law, the functions of the workplace union do not include carrying out work to assist management. ${ }^{38}$ The Vietnamese laws have articles against

35 Edmund Wehrle, “'Awakening the Conscience of the Masses': The Vietnamese Confederation of Labour, 1947-75", in Anita Chan (ed.), Labour in Vietnam, Chapter 2.

36 For instance, Jiang Mingdao, former chair of the Shanghai Municipal General Trade Unions, whom I had the opportunity to meet in the early 1990s, was fighting at that time to get the Shanghai government to index wages against inflation.

37 Anita Chan and Irene Nørlund, "Vietnamese and Chinese Labor Regimes: On the Road to Divergence", The China Journal, No. 40 (July 1998), p. 184.

38 Anita Chan and Irene Nørlund, "Vietnamese and Chinese Labor Regimes”, p. 184. 
exploitation that do not exist in the Chinese laws. The Vietnamese trade union is given the right to join international organizations and even to accept funding. The Chinese trade union law is silent on such a right. As a whole the Vietnamese Labor Law is superior to the Chinese in that the law grants the Vietnamese trade union more autonomy and therefore enables it to represent workers better.

It is a common belief that developing countries are lax in law enforcement. If we compare Vietnam and China, however, it does not seem coincidental that Taiwanese investors do not violate the Vietnamese labor laws in the same way that they flout the Chinese laws. Prohibitive articles accompanied by penalties in the Vietnamese law impose consequences on violators. One result is that the problem of unpaid wages, which is serious in China, is not prevalent in Vietnam.

There is also another factor. While in both the VGCL and the ACFTU the top levels of union officials are more pro-labor than the lower levels, in Vietnam this sympathetic outlook reaches down to the district level. Not so in China. As seen earlier, district-level local authorities and unions in Vietnam side with workers at times of strikes; but not their counterparts in China. There is a historical reason that district level governments in the HCMC region are more pro-labor. First, as the two countries' political systems loosened up and became more decentralized (this is more so in China, in that Vietnam is only the size and population of a Chinese province), the behavior of local governments has had a decided impact on the region's industrial relations system. In the HCMC region, where land had not been widely collectivized, ownership remains in the private hands of villagers and is inheritable. Provincial and district level governments, though they have an interest in attracting foreign investment, do not have a direct stake in renting out land and factory buildings to foreign companies. They are more ready to enforce the law and protect workers' rights than are local governments in China's Pearl River Delta. There, the land under Mao was owned by agricultural collectives, and today in Guangdong Province the agricultural collectives continue to own the land. They are often coterminous with natural villages and the revenues are controlled by the village governments. Large portions of agricultural land in the Pearl River Delta region have become industrial, and in most areas the land use rights still rest with the collectives, which have been actively constructing and renting out factory buildings to foreign investors for the past twenty-some years. Villagers, as a group, have become a rentier class. The very direct personal gains that can be made from foreign investors using migrant workers from poorer provinces contribute to the villagers' unconscionable disregard for the exploitation of the migrant workers by foreigners. ${ }^{39}$ The proportion of local villagers to migrant workers can be up to 1 to 100 , and no locals need to work at the production lines any more. There is an unspoken alliance between the local village governments (and the levels of government immediately above them) and foreign-invested enterprises with regard to keeping the migrant production-line workers in line.

39 Anita Chan, Richard Madsen and Jonathan Unger, Chen Village: Revolution to Globalization (Berkeley: University of California Press, 2009), Chapter 15. 
In both countries, the workplace union branches are weak. This is the level of interface between management and labor. There is a difference, however. In Vietnam, for instance, it was evident that the enterprise trade union branch at the ABC Factory saw itself as having an identity separate from management, even though it did not aggressively represent workers' interests and was too weak to play a role later in negotiating with management, letting the higher district-level union do this. I also have come across a case in which the trade union of a shoe factory in Vietnam that supplies Nike and other brand-name sport shoe companies is powerful enough to negotiate with management. Because it has been able to represent worker's interests, there has been no strike there, except for small-scale work stoppages.

In China, the workplace union branches in the private factories in the Pearl River Delta are worse than weak; in the factories where they do exist they are an integral part of factory management. Very often, a local villager is sent to the factory and given the title of deputy factory manager while simultaneously also holding the title of factory trade union chair. Often, workers do not even know of the existence of this virtual union.

Vietnamese workers at the ABC factory have a basic understanding of the importance of a collective agreement. For instance, they insisted that certain demands be written into the contract even though some of those demands were already implemented in practice. In China, however, it became obvious in talking to workers and to labor NGOs that the concept of collective bargaining is practically unknown in the Pearl River Delta. Though collective bargaining has a legal status, it was only in August 2008 that the ACFTU, with Party-state backing, launched a campaign of "collective consultation", urging workplace unions to draw up collective agreements with management. The campaign fired its first shot by targeting China's hundred-some Wal-Mart stores, ${ }^{40}$ but close examination of the collective agreement at a Wal-Mart store that was held up as a model reveals serious procedural irregularities and a collective contract in which the staff's wages were unlikely to keep abreast of inflation. ${ }^{41}$

\section{The Tripartite Institutional Framework}

Countries with longstanding union movements often maintain industrial peace through a well-established tripartite system that involves the state, labor and employers. Urged on by the ILO, in the early 2000s both Vietnam and China set up Tripartite Consultative Committees (TCCs) composed of the state, employers' associations and the trade union federation. These were established at various levels,

40 Anita Chan, "Unionizing Wal-Mart's Chinese Stores", in Anita Chan (ed.), Wal-Mart in China (Ithaca: Cornell University Press, forthcoming 2011).

41 China Labor News Translations (CLNT]), "Promising Wal-Mart Chair Resigns Over Collective Contract Negotiations", 22 September 2008, www.clntranslations.org/article/34/promising-walmart-trade-union-chair-resigns-over-collective-contract-negotiations (accessed 14 April 2010). 
as platforms for three-party dialogue. ${ }^{42}$ The Vietnamese TCC system is better developed than is China's. ${ }^{43}$

Vietnam and China both have strong states, weak workplace-level union representation and well-organized union federations that play a role at the national level. The VGCL in Vietnam, being more independent from the state, can assert its opinions more openly than can the ACFTU in China. In both countries, due to a socialist past, employers' associations are new and not well developed. The Vietnamese Chamber of Commerce and Industries (VCCI) appears to represent its members' interests better in the Tripartite Consultative Committee ${ }^{44}$ than does its Chinese counterpart. Perhaps this explains a softer approach taken by foreign investors in their handling of strikes. For instance, in interviews at a big foreign company in Vietnam, it became clear that an intensive tripartite dialogue took place in early 2006 when a strike wave broke out. By contrast, the Chinese Enterprise Management Association (Zhongguo qiyejia xiehui 中国企业 家协会) has not been as well developed, and its representation on China's Tripartite Consultative Committee is weak. A study of the Chinese TCC concludes that, several years after its establishment, its operations still fell far below the standards set by the ILO. ${ }^{45}$ The fact that the VCCI has a role to play in Vietnam helps to explain why the ILO office there has successfully exerted some influence in shaping the industrial relations system. As one example, in April 2010 the ILO office in Vietnam and the Ministry of Labor jointly organized a tripartite conference to discuss draft revisions of the Labor Code and the Trade Union Law.

\section{Legal Procedures Regulating Strikes}

After intense debate, the Vietnamese law granted workers the right to strike, laid out in a detailed set of procedures. The Chinese Labor Law does not mention strikes at all, effectively putting this right in limbo. Strikes in China are not legalized, nor are they illegal. While critics take China to task for not having recognized the right to strike, it is not mentioned that there are also no provisions prohibiting strikes or defining what constitutes an illegal strike. In fact, Chang Kai, a Chinese academic and an authority on China's labor laws who has been arguing for the right to strike, interprets the law as tantamount to "China recognizing

42 Lee Chang-Hee, "Recent Industrial Relations Developments in China and Viet Nam: The Transformation of Industrial Relations in East Asian Transition Economies", Journal of Industrial Relations, Vol. 48, No. 3 (2006), pp. 415-29.

43 Ibid.

44 For example, Radio Voice of Vietnam, "New Model Needed to Ensure Labor Harmony" (http://english.vovnews.vn?Utilities?PrintVietn.aspx?ID=99832), 12 February 2009, accessed 22 April 2009.

45 Jie Shen and John Benson, "Tripartite Consultation in China: A First Step Towards Collective Bargaining”, International Labour Review, Vol. 147, Nos. 2-3 (2008), pp. 232-48. 
the right to strike". ${ }^{46}$ In a heated debate in Chinese labor circles, others took an opposing view, arguing that such an interpretation would encourage more strikes. The pros and cons of having a legal regulatory procedure with regard to strikes are complex.

\section{China's and Vietnam's Labor Laws}

The Labor Laws passed in 1994 in the two countries established institutions and procedures to channel industrial disputes through a three-stage formal proceeding: an enterprise level conciliation committee, an arbitration committee that is external to the enterprise and, lastly, the court system. In practice, because the workplace unions serving as the representatives of labor on the conciliation committees are weak and often are controlled by management, workers do not go to them to resolve grievances. Instead, they go directly to the arbitration committee. If they are dissatisfied with the committee's decision, workers can appeal to the local court.

On 1 January 2008, a new Chinese law, the Labor Dispute Conciliation and Arbitration Law, came into effect. The new law was needed, since disputes had skyrocketed from 19,000 in 1994 to 317,000 in 2006, of which 14,000 cases were collective disputes entailing demonstrations or strikes, sometimes involving violence. ${ }^{47}$ However, like its predecessor, the new law fails to make a distinction between individual and collective disputes, nor does it distinguish between rightsbased and interest-based protests, or legal and illegal industrial actions. The terms "collective bargaining", "strike" or "work stoppage" are also absent. The only reference to any form of collective dispute is contained in Article 7: "Where the party in a labor dispute consists of more than 10 laborers, and they have a joint request, they may recommend a representative to participate in mediation, arbitration or litigation activities". However, the procedure for these collective disputes is the same as for an individual. In practice, even when a group of workers with the same complaint applies for arbitration, they are often dealt with as individual cases.

This new law tries to rectify many of the problems that had previously placed workers at a disadvantage when they used legal proceedings to resolve their grievances. For instance, a worker used to have to file a complaint within 60 days of the moment that the labor rights infringement took place. This has been lengthened to one year in the new law, which is helpful to workers who need a longer period to seek help to file a case. Workers now no longer have to pay an arbitration fee, which had been a major financial burden, especially when their cases had to do with unpaid wages. The maximum period given to an arbitration committee to decide

46 Chang Kai, "Gongren jiti yishi yu laodong guanxi zhuanxing" (Workers' Collective Consciousness and Changing Industrial Relations), http://new.21ccom.net/articles/zgyj/ ggzc/article 2010091819365.html (accessed 5 November 2010).

47 Ronald Brown, “China Labour Dispute Resolution”, Foundation for Law, Justice and Society, 2008, p. 1 (www.fljs.org/uploads/documents/Brown\%231\%23.pdf) (accessed 6 November 2010). 
whether to accept a case is now shortened to 5 days, and the maximum time for a ruling is 10 days. An arbitration ruling is now compulsory (Article 47), and because only the employee, not the employer, has the right to a court appeal (Article 48), a ruling in the workers' favor cannot be overturned or dragged on and on at court. Due to these changes favorable to workers, within half a year of the law's promulgation there was an explosion of cases lodged at Shenzhen city's arbitration offices-23,785 applications, 243 per cent more than for the same period in 2007; of these, 22,122 cases were accepted for processing. The arbitration staff was overwhelmed. ${ }^{48}$

An important difference between the Chinese and Vietnamese laws is that the Vietnamese Labor Law makes a distinction between individual and "collective labor disputes" and has separate sections laying down the procedures for dispute resolution. ${ }^{49}$ For collective disputes, workers can take their case to an arbitration council at the district level composed of "full-time and part-time members from the labor administration system, union, employers and lawyers' association, or experts in industrial relations in the locality" (Article 170). Like other countries, for example Australia, collective strike action is not allowed while arbitration is in process.

In Vietnam a distinction is also made between rights-based and interest-based disputes. Rights-based disputes are those related to legal violations and are dealt with by the chair of the District People's Committee. The maximum time given to decide on a resolution is five working days (Article 170a). If the workers disagree with the resolution, they can begin strike procedures. For labor disputes that do not involve charges against the employer for legal violations, the maximum time for the arbitration body to arrive at a decision is seven days. The decision has to be sent to the disputants within two days. The trade union then has to organize a secret ballot. A majority vote is needed from among the employees in enterprises with up to 300 workers, and the consent of over 75 per cent of "consulted workers" must be gained in enterprises of more than 300 workers, before the union executive branch can present workers' demands and notify the employer of the time and place of the impending strike (Article 174b). Short of those percentages, the workers cannot legally hold a strike. The notification has to be delivered to the employer, the Labor Ministry and the provincial union federation five days prior to the scheduled strike (Article 174b).

The proof of the pudding is in the eating. Despite these legal requirements, none of the several thousand known strikes in Vietnam to date has been legal, in that they have not complied with these regulations. As we have seen, the number of strikes

48 The great increase in cases may also have been caused by other factors such as the Contract Law that came into effect at the same time. Ye Minghua, "Shenzhen shi shangbangnian laodong zhongcai'an bizeng 243\%" (In First Half of This Year Shenzhen City Labor Arbitration Cases Jumped 243\%), Chinese Labor Dispute Net, 13 August 2008, www.btophr.com/b article/19514.html, accessed 23 October 2008.

49 Van Thu Ha, "Viet Nam", Rights for Two-Thirds of Asia: Asian Labor Law Review 2008 (Hong Kong: Asia Monitor Resource Centre, 2008), pp. 224-26. 
has continued to rise-and these were all wildcat strikes which bypassed the procedures. The law has been ignored.

A major reason is the complicated procedure for applying to hold a legal strike. This is impractical for strike organizers: Taiwanese factory managers with no tradition in engaging in collective bargaining in Taiwan cannot be trusted to await complicated and lengthy pre-strike procedures without using the opportunity to ferret out the strike organizers and to get rid of them. Workers ask themselves why they should bother to take the cumbersome legal route when they can go on strike spontaneously, as has been the case for the last decade, with a high chance of winning and at little personal risk. As a result, all strikes have been wildcat, and worker representatives have not applied to stage a strike.

In short, the Vietnamese and Chinese governments have taken different approaches. Vietnam has always recognized the right to strike, but by doing so has rendered technically illegal all the strikes that have taken place. What is interesting is that, although workers refuse to play by the rules, the authorities do not enforce the law. They are not arresting and prosecuting illegal strikers, but instead are bargaining on their behalf with management. By contrast, the Chinese government tries to control the spread of strikes by simply not recognizing either collective industrial actions or the right to strike. At the same time, however, China cautiously continues not to make strikes illegal, leaving this a grey area. It tries to channel all grievances through legal processes and has enacted a law making this easier for the workers, resulting in a vast increase in individuals' litigation. However, because the state does not lay down any procedure for collective actions, when strikes do erupt the authorities react by trying to suppress them. The contrast between the two countries can be reduced to this - in Vietnam it is a situation of "harsh laws, soft implementation"; in China it is "soft laws, harsh implementation".

\section{Labor Standards: Rights-based vs. Interest-based Protests}

The distinction between rights-based and interest-based disputes is never particularly clear-cut, but in conceptual terms, especially within a comparative framework regarding Vietnam and China, the distinction is useful. ${ }^{50}$ As already pointed out, Vietnamese labor protests tend to be interest-based while Chinese protests tend to be rights-based. Vietnamese workers' demands go further than just the minimal legal standards. They want job security and a seniority system. On the other hand, for about two decades Chinese workers have tended to seek no more than being paid at least the legal minimum. ${ }^{51}$ In two case studies of strikes

50 Scholars writing about "rights defense" in China tend not to make this distinction. For instance, Yongshun Cai, "Social Conflicts and Modes of Action in China", The China Journal, No. 59 (January 2008), pp. 89-109; Hualing Fu and Richard Cullen, "Weiquan (Rights Protection) Lawyering in an Authoritarian State: Building a Culture of PublicInterest Lawyering”, The China Journal, No. 59 (January 2008), pp. 111-27.

51 There are, however, signs that the problem of wage arrears has improved, partly because the government has begun to take a stronger stand against it. This is based on observation by a Shenzhen labor NGO staff member. 
described by Chris Chan and Pun Ngai, the workers, like those at Stella, rose up because of a sudden drop in wages; when converted to yuan per hour, their demands for a wage rise did not go beyond the legal minimum. ${ }^{52}$ Because their rights are being violated, and because they have no organized bargaining power, this is all they can realistically ask for.

In part, this distinction between disputes in the two countries has to do with the labor standards set by the two governments. The higher the government's standards, the higher the chance that they are being breached by employers. China's legal regular work hours are set at a 40-hour week, with a maximum of 36 hours of overtime hours per month. Vietnam's is set at a 48 -hour week, with a maximum of four hours of overtime per day, capped at a maximum of 300 hours per year if permitted by the government after management applies to raise it above 200 hours. This means a maximum average of working hours for China is 49 hours per week; for Vietnam, it is 57 hours. A Taiwanese employer operating factories in both countries and wanting workers in both to work 60 hours per week (the maximum allowed by most corporate codes of conduct) will have to violate both countries' laws. However, the violation under Chinese law will be much higher (11hours/week) and therefore more serious than under Vietnamese law (3 hours/week). In other words, it is easier for management to stay within the legal maximum in Vietnam than in China.

Similarly, with regard to setting wages, Chinese local governments have been adjusting the minimum wage every year based on a formula commensurate with the local cost of living. Thus, an increase in the minimum wage normally covers inflation. On the other hand, for a period of six years until 2006, the Vietnam government did not make adjustments to the minimum wage. When it finally did raise the minimum wage (almost invariably used by foreign employers as the base wage), the increase did not catch up with double-digit inflation. According to Corpwatch, during the period when the minimum wage remained stagnant Vietnam's currency dropped almost 15 per cent against the US dollar, and inflation reached 28 per cent. ${ }^{53}$ The legal minimum wage was so low that, when Vietnamese workers staged labor protests to catch up with the high inflation, they were struggling for their interests rather than for their legal rights, which had not been infringed.

\section{The Trend Lines in Industrial Relations Patterns}

Without effective union representation at the foreign-owned factories, both Vietnamese and Chinese workers rely on the state to help them. They make economic demands on their employers, but make no demands regarding state policy (for instance, they do not demand that the officially set minimum wage be increased) nor political demands (for instance, they do not demand autonomous trade unionism). In both countries, strikes are aimed at appealing to local authorities

\footnotetext{
52 Chris King-Chi Chan and Pun Ngai, "The Making of a New Working Class?”.

53 Aaron Glantz and Ngoc Nguyen, "Happy Meals, Unhappy Workers", Corpwatch, www.corpwatch.org/print article.php?id=13358 (accessed 15 March 2006).
} 
for help. In Vietnam, the workers go on strike in order to get the local state to negotiate on their behalf. In China, collective actions take the form either of violence at the workplace or, more often, of street actions such as marching to local government offices to ask that pressure be applied on their employers. Vietnamese and Chinese workers remain at the stage of seeking government protection, unlike Indonesian workers, who hold mass rallies calling on the government to raise the minimum wage. This reflects a difference in the state-worker relationship between the formerly "socialist" states and the developing-nation capitalist states.

State power is exercised differently in Vietnam and in China. The Vietnamese government uses its administrative power to demand interest-based improvements in foreign-owned factories. For instance, during the $\mathrm{ABC}$ strikes, government representatives pushed $\mathrm{ABC}$ management to set up a seniority-based year-end bonus system and an incremental salary system based on years of service. ${ }^{54}$ The government also tries to push brand-name clients to force their suppliers to set up these systems. ${ }^{55}$

The Chinese government does not normally resort to direct administrative intervention to get employers to provide a better deal for workers. Instead, it put a new Contract Law into effect in 2008 which requires employers to sign open-ended contracts with those employees who have already signed two fixed-term contracts and with workers who have had 10 years of service (Article 14 [1] and [3]). This provides such employees with more secure employment. It is up to the employers to abide by the law, and if they do not it is up to an individual employee to use the law to fight for this legal right through arbitration. This ultimately means more litigation in China. In short, whereas the Chinese government has not used any law to regulate strike disputes, the state does resort to a different tactic to avert strikes - by individuating all labor disputes and channeling them through the arbitration and court systems, causing a proliferation of litigation cases in China over the past decade.

In turn, this has led to the emergence and proliferation of legal aid clinics, labor NGOs, labor lawyers and paralegals in the Pearl River Delta. They help individual workers in their fight to secure wage arrears and compensation for industrial injuries. No fewer than 500 people in the Pearl River Delta are currently working professionally as labor-rights protectors, and among them more than 20 have had a significant influence. There are many more non-professional legal practitioners who began as workers fighting their own personal cases and who, having learned the ropes through self-education, started helping others by becoming what in China today are called "citizens' agents" (gongmin dailiren 公民代理人). One such agent has become famous in the past decade-and-a-half by handling 6,000 cases. As these citizen's agents become more knowledgeable and skilled in litigation, some workers have been awarded substantial amounts in back pay and in compensation for injuries. In one case, an employer in Shenzhen city was so infuriated that he hired thugs

\footnotetext{
54 Notably, state guidelines require each enterprise to develop its own salary tables and scale, to be filed with the local government department for approval (Van Thu Ha, "Viet Nam", p. 222).

55 Information from a human resource manager of a large Taiwanese supplier (Interview conducted by Wang Hongzen 30 November 2006 in Taiwan).
} 
to smash up a legal-aid NGO office and subsequently arranged for the NGO head's legs to be severed with a cleaver during a streetside attack. This incident raised great alarm among the labor NGO community in Shenzhen. The rise of litigation and of citizens' agents has catapulted China's industrial relations into a new stage. In response, the Guangdong government has begun to grapple with the question of whether it should attempt to co-opt and incorporate the citizens' agents and other labor-rights protectors by bringing them under its wing. ${ }^{56}$ This initiative potentially places these now-independent advisors on workers' litigation in a vulnerable position, constantly at the mercy of the authorities. ${ }^{57}$

The legal aid movement has been instrumental in raising workers' awareness of their labor rights, but the very fact that the movement is framed by the discourse on "rights protection" (weiquan 维权; wei meaning to protect; quan meaning rights) further individualizes labor dispute settlements in a reactive manner. Only when labor rights (that is, specific minimal legal rights) are being violated do workers come out. The Chinese language contains a compound word quanyi (权益; quan meaning rights; $y i$ meaning interests) but when this word is used in China today about labor issues it refers almost exclusively to legal rights, not to interests.

This narrow focus on legal rights has a delimiting effect on workers' consciousness. Beyond the legal minimum, their interests are not protected by law and do not come within the purview of the legal aid personnel. Struggling for interests is a pro-active behavior that can best be achieved by collective bargaining, but the idea of collective bargaining has not yet penetrated the consciousness of the vast bulk of Chinese workers. Due to institutional, legal, political and social constraints, it will be some time before China will develop an industrial relations system in which workers' interests can be voiced and genuinely represented by the ACFTU. Instead, China has been heading in a direction that is becoming increasingly litigious, interrupted sporadically by industrial violence. There have been a handful of known cases of workers trying to demand participatory rights in the moribund workplace-level trade union branch, or, where a union does not exist at a factory, trying to establish their own elected union branch under the ACFTU umbrella, ${ }^{58}$ but this kind of demand is as yet unusual,

56 China Labor News Translations, "A New Precedent: Shenzhen Furniture Factory Worker Wins Two Years of Overtime Back Pay", November 2007; "Shenzhen Labor Activist Attacked", December 2007; "Labor NGOs in Guangdong Province", January 2008. All available at http://www.clntranslations.org/archive/, accessed 2 December 2009.

57 China Labor News Translations, "Chinese Labor NGOs and Free Legal Services Always in a Precarious Situation", January 2010, http://www.clntranslations.org/archive/, accessed 22 October 2008.

58 For instance, in 2006 workers in a Danish-owned firm in Shandong Province went on strike to set up a workplace union. The workers had to struggle with the management, the district government and the trade union for several years, until the owner closed down the factory. This long story is documented in China Labour News Translations, in "Workers Fight to Save their Union Activists", 16 October 2008; and "Ole Wolff Union Struggle, Part Two", 10 March 2009, at http://www.clntranslations.org/archive/, accessed 17 November 2010. 
and there are no signs that the local authorities want to enable workers to have a say in their own union branches or in collective bargaining.

At the same time, however, there are very recent signs that some workers are willing to act to advance their interests when an opportunity arises. In mid-2010, workers at a Honda factory in Guangdong manufacturing transmissions spontaneously went on strike, initially demanding a wage rise of about 60 per cent. Within days, local men wearing hats identifying them as union staff came to beat up the strikers. ${ }^{59}$ When photographs of the scuffle appeared on the web, generating embarrassing publicity for the union, the provincial union stepped in to intervene on the strikers' behalf. They received a wage rise of 24 per cent, ${ }^{60}$ plus a promise by the provincial union that they would be able to elect their own enterprise union committee. However, it was already known that the official minimum wage was due to rise the following month by 20 per cent, which meant that some of the strikers achieved a rise of only 4 per cent above the new mandatory minimum wage. Though the victory was modest, this was the first publicized interest-based strike in China in recent times, and its success prompted copycat walkouts at a few other Honda parts plants in Guangdong. ${ }^{61}$ The new strikes met with only mixed success, however, and the small ripple of industrial actions soon petered out. Since then, the success of the initial strike has been whittled away. The Guangdong provincial union has reneged on its promise by postponing the election of the trade union chair and the trade union committee until the following year when the term of the current union committee is due to expire. This move serves two purposes. It will prevent demands by workers to replace management-controlled unions through new, democratic elections from becoming a precedent; also, in several months few former strike leaders will be able to be elected, as many of the plant's strikers will probably have moved on to a new employer, replaced by entirely new recruits. ${ }^{62}$ Despite these setbacks, the Honda strikes may possibly be a harbinger of a new era in interest-based worker demands. What is most noteworthy is that, for the time being, the great bulk of Chinese industrial protests are still in the stage of simply seeking to protect workers' minimum legal rights.

Another well-documented case involved Uniden, a Japanese firm. See, for example, South China Morning Post, 21 April 2005.

59 "Bentian bagong zuixin jinzhang-yuangong beida" (New Development with the Honda Strike-Workers Beaten Up), 30 May 2010 at http://blog.sina.com.cn/u/1297177460, accessed 2 June 2010.

60 Norihiko Shirouzu, "Honda Offers Strikers in China 24\% Pay Boost", Wall Street Journal, 31 May 2010.

${ }^{61}$ John Chan, "China: Honda Lock Strike Continues", 15 June 2010 (http://www.wsws.org/ articles/2010/jun2010/chin-j15.shtml), accessed 24 June 2010.

62 This information is based on oral reports by four Zhongshan University graduate students in October 2010 on what happened at the plant after the workers had returned to work. The students had been to the plant several times between June and October and had interviewed quite a few workers, the local unions and some officials. 
What, then, may we conclude overall from this comparison of Chinese and Vietnamese strikes in foreign-owned plants? Worker demands differ markedly in the two countries, as do the normal resolutions of strikes. These very different outcomes, as we have observed, owe much to the historical experiences of the two countries, the relations between the local governments and factory owners, the relationship between the government and the official trade union, the labor laws, the tripartite dispute-resolution institutions and the minimum legal labor standards set by the government.

A further conclusion relates to the legal framework for strikes. The Vietnamese experience shows that a strike law does not automatically translate into workers following the law when they go on strike, nor does the grey zone created in China by the absence of a law give free rein to strikes there. Nevertheless, we have observed that the legal framework matters. The experience of the past one-and-ahalf decades in China and Vietnam shows that the cynics' argument that laws do not count because they are not enforced is wrong. When we compare the two countries, it becomes evident that their laws have helped to set the foundations and frameworks for path-dependent evolution in their patterns of industrial relations, albeit in a complicated, counter-intuitive fashion. 


\section{CONTRIBUTORS TO THIS ISSUE}

Anita Chan is a Research Professor at the China Research Centre of the University of Technology, Sydney. She has published widely on Chinese labor issues, rural China and Chinese youth, and also comparatively on Vietnam. She recently co-authored Chen Village: Revolution to Globalization (University of California Press, 2009) and is the editor of Wal-Mart in China (Cornell University Press, 2011) and of Labor in Vietnam (Institute of Southeast Asian Publishing, 2011). She is now involved in a new research project on China's auto industry.

Alex Cockain is Academic Coordinator and lecturer on an International Foundation Programme which runs within Tsinghua University's School of Continuing Education. His teaching includes courses such as Theoretical Approaches to Media, Culture and Society, Introduction to Social Science and Social Research Methods. He earned a $\mathrm{PhD}$ from the University of London, School of Oriental and African Studies in 2009 for an anthropological study of Chinese youth.

Guosheng Deng is Associate Professor and Director of the Center for Innovation and Social Responsibility in the School of Public Policy and Management at Tsinghua University.

DONG Guoqiang is Professor of History at Nanjing University, where he also teaches in the Johns. Hopkins-Nanjing University Center for Chinese and American Studies. During the 2008-09 academic year he was a Fellow at the Stanford Humanities Center. His primary research interest is the history of the Cultural Revolution at Nanjing University and in Jiangsu Province.

Christian Göbel is a postdoctoral fellow at the Centre for East and South-East Asian Studies at Lund University, Sweden. He is the author of The Politics of Rural Reform in China: State Policy and Village Predicament in the Early $2000 \mathrm{~s}$ (Abingdon and New York: Routledge, 2010) and the co-author with Thomas Heberer of The Politics of Community Building in Urban China (Abingdon and New York: Routledge, 2011). In addition, he has published several articles on rural reforms and central-local relations in China. His current research project compares regime maintainance strategies in China, Burma and Laos.

J. Bruce Jacobs is Professor of Asian Languages and Studies at Monash University in Melbourne, Australia.

Teresa Kuan is an Andrew W. Mellon postdoctoral fellow in the Department of Anthropology at Whittier College. 
Search Workspace Ulrich's Update Admin

Enter a Title, ISSN, or search term to find journals or other periodicals:

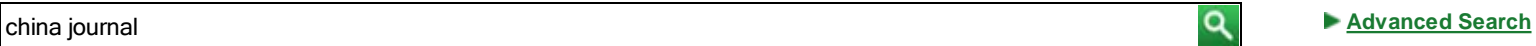

\section{The China Journal}

\section{Title Details Table of Contents}

\begin{tabular}{|c|c|c|}
\hline Related Titles & \multicolumn{2}{|c|}{ 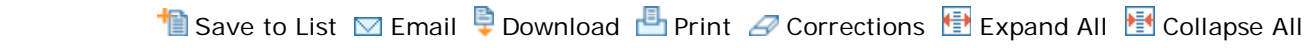 } \\
\hline \multirow{2}{*}{$\begin{array}{l}\text { Alternative Media } \\
\text { Edition (2) }\end{array}$} & \multicolumn{2}{|l|}{ V Basic Description } \\
\hline & Title & The China J ournal \\
\hline \multirow{2}{*}{ Lists } & ISSN & 1324-9347 \\
\hline & Publisher & Contemporary China Centre \\
\hline \multirow{2}{*}{$\begin{array}{ll}\text { Marked Titles } & (0) \\
\text { Climate change } & (45)\end{array}$} & Country & Australia \\
\hline & Status & Active \\
\hline \multirow{2}{*}{ Search History } & Start Year & 1949 \\
\hline & Frequency & Semi-annually \\
\hline \multirow[t]{18}{*}{ china journal } & Language of Text & Text in: English \\
\hline & Refereed & Yes \\
\hline & Abstracted / Indexed & Yes \\
\hline & Serial Type & Journal \\
\hline & Content Type & Academic / Scholarly \\
\hline & Format & Print \\
\hline & Website & http://rspas.anu.edu.au/ccc/journal.htm \\
\hline & Description & $\begin{array}{l}\text { Focuses on topics relating to China, Hong Kong and Taiwan since } 1949 \text {, plus } \\
\text { studies of the major issues that contribute to understanding of Communist } \\
\text { Party history and contemporary events. }\end{array}$ \\
\hline & \multicolumn{2}{|c|}{ Subject Classifications } \\
\hline & \multicolumn{2}{|c|}{ - Additional Title Details } \\
\hline & \multicolumn{2}{|l|}{ - Title History Details } \\
\hline & \multicolumn{2}{|c|}{ - Publisher \& Ordering Details } \\
\hline & \multicolumn{2}{|c|}{ - Price Data } \\
\hline & \multicolumn{2}{|l|}{ - Online Availability } \\
\hline & \multicolumn{2}{|c|}{ Abstracting \& Indexing } \\
\hline & \multicolumn{2}{|c|}{ Other Availability } \\
\hline & \multicolumn{2}{|l|}{ Demographics } \\
\hline & \multicolumn{2}{|l|}{ - Reviews } \\
\hline
\end{tabular}

